\title{
SSynthesis
}

International Scientific Conference of IT and Business-Related Research

\section{KAUZALNOST MEDIJA I AGRESIJE}

\section{UNDERSTANDING THE CAUSAL RELATIONSHIP BETWEEN MEDIA AND AGGRESSION}

\author{
Bisera Jevtić ${ }^{1}$, Aleksandar Vasić ${ }^{2}$ \\ ${ }^{1}$ Filozofski fakultet Niš, Srbija \\ ${ }^{2}$ Visoka škola strukovnih studija za vaspitače Kruševac, Srbija
}

\begin{abstract}
Apstrakt:
Posmatranje nasilja na različite načine i kroz raznovrsne vidove tehnologije, može dovesti do učenja i kasnijeg ispoljavanja takvog ponašanja kao i do širenja predrasuda o određenim grupama. Izloženost medijskom nasilju izaziva agresivno ponašanje, te je stoga verovatno da izraženo agresivne ličnosti, imaju visok nivo kontrole ka nasilnom medijskom sadržaju. Ovakva dvosmernost je široko razmatrana, pri čemu je proizvela mnogobrojna istraživanja sa različitim zaključnim osvrtima. Dvosmerni efekti postoje, što znači da se kreću u dvosmernim pravcima. Naš rad se bavi komparativnom analizom relevantne literature koja se tiče različitih posledica dečije izloženosti medijskom nasilju i subjekata koji su obuhvaćeni, kao i faktorima koji povećavaju nivo agresivnosti usled medijskog uticaja nasilnih sadržaja.

Pošto percepcija ličnosti igra važnu ulogu u osnovnim efektima medijskog nasilja, pretpostavlja se da promena percepcije može redukovati ovakav efekat. Jedna od mogućih strategija koja otklanja negativne efekte medija jeste razvijanje medijske kompetentnosti koja omogućava pojedincu da se zaštiti od manipulacije medija, ali i da iskoristi nihove pozitivne aspekte. Kako bi uspeh strategije bio delotvoran, potrebno je upoznati se sa navikama mladih, učestalošću korišćenja medija, sadržajem medija kao i proveriti aktuelni nivo medijske kompetencije. Za navedene aspekte, kao sugestija u daljem istraživanju, korisno je primeniti drugačije pristupe sa naglašenim isticanjem konteksta istraživanja i njegovog sadržaja.
\end{abstract}

\section{Ključne reči:}

medijsko nasilje, agresivnost, efekti medija, medijske kompetencije.

\section{UVOD}

U peridu predglobalizacije, dominantni i relevantni agensi socijalizacije dece i mladih bili su porodica i škola. U vreme globalizacije, sve veći značaj pa čak i prevlast dobijaju mediji.

Moderne tehnologije značajno su uticale na način komunikacije među ljudima. Poslednjih godina sve više raste zabrinutost da široka upotreba medija vodi ka otuđenosti i usamljenosti pojedinca. Mediji ne samo da definišu način komunikacije već često određuju i njen sadržaj. Nametanje kulturnih normi utiče na organizaciju, pre svega, grupa mladih koji preuzimaju način života svojih idola. Ne samo da mediji određuju način komunikacije i ponašanja nego promovišu određene vrednosti kao prihvatljive i poželjne (Mandarić, 2011).

Digitalne tehnologije su dodate već kompleksnoj slici izlaganju medijima, tako da njihov efekat na socijalizaciju varira. Ukazivalo se da, vreme koje se posvećuje digitalnim tehnologi-

\section{Abstract:}

The observation and analysis of violence by means of different methods and various forms of technology can lead to adopting and subsequently manifesting such behavior, as well as to spreading prejudices towards certain groups. Exposure to media violence causes aggressive behaviour, and it is therefore likely that extremely aggressive personalities will have a high level of control concerning violent media content. Such two-way relationship has been widely discussed, thus triggering numerous studies with different conclusions. Two-way effects exist, which means that they are moving in two-way direction. Our paper deals with a comparative analysis of the relevant literature concerning the different consequences of children's exposure to media violence and the subjects involved, as well as the factors that enhance the level of aggressiveness due to exposure to violent media content.

Since the perception of personality plays an important role in primary effects of media violence, it can be assumed that a change of perception can reduce such effects. One possible strategy that eliminates negative effects of the media is to gain media competence that allows the individual to be protected from media manipulation, but at the same time take advantage of the positive aspects of the same. In order to make the strategy more efficient, it is necessary to become familiar with the habits of the young people, the frequency of media usage, media content, as well as to check the current level of media competence. As a suggestion for further research concerning these aspects, it may be useful to apply different approaches with an emphasis on research context and content.

\section{Key words:}

media violence, aggression, media effects, media competences.

jama, kao i vreme koje se posvećuje drugim medijima ide na štetu, odnosno, oduzima vreme koje se provodi sa porodicom, gde se interakcija odvija licem u lice, odnosno ličnim kontaktom.

Prilikom komunikacije posredstvom kompjutera fizičko prisustvo nije zahtevano, pa tako dolazi do pozitivnih i bliskih veza, poruke koje su upućene mogu biti shvaćene pogrešno ili nejasno, a primetan je i nedostatak relacionih znakova koji proističu iz fizičkog konteksta, kao i neverbalnih znakova koji su u vezi sa pokretima tela, facijalnom ekspresijom, glasom i naravno, celokupnim fizičkim izrazom (Šmakić, 2012).

Ne samo da je poželjno da se neutrališe negativni uticaj medija, nego bi moć medija trebalo iskoristiti u edukativnu svrhu kao i u svrhu podsticanja moralnog i socio-kognitivnog razvoja dece i mladih. Identifikovanjem određenih pravilnosti kao i uzročno-posledične veze moguće je konstruisati detaljan plan prevencije negativnih uticaja razvijanjem medijske kompetentnosti koja omogućava pojedincu da se zaštiti od manipulacije medija, ali da istovremeno iskoristi pozitivne aspekte istih. 


\section{TEORIJSKO-METODOLOŠKA ORIJENTACIJA}

Reč agresija u svakodnevnom govoru najčešće ima negativnu konotaciju. Agresivnost se odnosi na napadanje, nasiliničko ponašanje koje uključuje destruktivne i štetne akcije prema ljudima i/ili predmetima a čiji je cilj nanošenje štete ili boli. Agresivno ponašanje može biti reakcija na izazov, provokaciju ili ometanje, ali isto tako ne mora biti ničim izazvana. Reč agresija izvedena je od latinske reči aggredi što znači napasti (Stanić, 2008).

Postoji određena terminološka zbrka oko toga šta predstavlja agresivno ponašanje, a šta nasilje. Često se ovi termini koriste i kao sinonimi. Popadić (2009) je pokušao da ponudi razgraničenje ovih termina.

On smatra da je bitna odlika nasilja da je ono namerno i neopravdano nanošenje štete. Iako se i agresija može definisati na isti ili bar sličan način, Popadić ističe da se agresivnost može ispoljavati i kao potencijal koji nije nužno doveo do nanošenja štete i boli. Tako u stvari agresija predsavlja širi pojam od nasilja. Naime, Popadić smatra da je nasilje u stvari realizovana agresija. Još jedna bitna razlika između nasilja i agresije je neopravdanost. Dakle, nasilje je uvek neopravdana i preterana akcija, dok agresija ne mora nužno biti.

Različite podele agresije i agresivnog ponašanja akcenat stavljaju na različite aspekte kao i posledice agresivnosti. Tako je moguće razlikovati napadačku i odbrambenu agresivnost.

Za razliku od napadačke agresije koja za cilj ima namerno nanošenje štete, odbrambena agresija je adaptivna i služi samoočuvanju. Međutim, ukoliko je reakcija izražena i praćena velikim i ozbiljnim posledicama, onda se odbrambena agresija pretvara u destruktivnu (Bilić, 1999).

Uloga medija posebno se smatra važnom u adolescenciji, $\mathrm{u}$ vremenu nesigurnosti, intimnih i osetljivih pitanja. Adolescent ta pitanja ne želi da deli sa drugima, već najčešće pribegava medijima, odnosno medijskom sadržaju. Mediji, kao moćno sredstvo kontrole i manipulacije, putem moćnih mehanizama i tehnika, proizvode stereotipe, koji za rezultat mogu imati stigmatizaciju neke društvene grupe, kao što je etiketiranje. Određene predstave o nekoj grupi, mogu se duboko ukoreniti, ako se učestalo prikazuju putem medija, jer se učestalo i nepekidno ponavljanje neistine vremenom transformiše u ono što je tzv. istina, pogotovu kada se verodostojnost informacije ne može proveriti (Burić, 2010).

Kada se, nakon takvih i sličnih događaja, počnu uviđati prvi znakovi razaranja porodice, neminovan je i predvidiv sled događaja unutar šire društvene zajednice, a samim tim, tako polakomljenim i nestabilnim mnogo je lakše manipulisati i upravljati (Dmitrović, 2011).

Mediji, osim što nude određene stereotipe ponašanja, oni i usmerevaju događanja koja su značajna za ljudsku zajednicu. Takođe, izveštavaju o različitim vrstama nasilja, pokazuje ga autentičnim snimcima, opisuju, dočaravaju postupak simulacije.

Virtuelna stvarnost nudi dečijoj mašti i znatiželji gotove predstave, projekcije junaka koji postaju njihovi lideri i identifikacioni modeli. Mladi ljudi takođe su podložni televizijskom uticaju, posebno u adolescentnom periodu, kada je njihov karakter labilne prirode, sklon konstantnom menjanju i prilagođavanju mnogobrojnim uticajima, posebno uticaju medija, kao najzastupljenijem činiocu u životima mladih ljudi (Stojković, 2012).

Ovaj oblik nasilja se dosta razlikuje od realnog, odnosno stvarnog nasilja, a glavna razlika je u korišćenju sredstava kojima se ono ostvaruje. Mnogi adolescenti i mladi upuštaju se u virtuelno nasilje, jer je to fenomen koji omogućuje anonimnost. Korišćenje različitih lozinki i lažnih imena pruža mogućnost skrivanja sopstvenog identiteta, preuzimajući virtuelni, mladima je omogućena sloboda u vidu postupanja i predstavljanja drugim osobama. Takav način ophođenja sa žrtvom iziskuje manje energije i ličnog rizika, koji prati suočavanje licem u lice. Jednostavnije je ranjavati drugo lice sakriven iza lozinke i lažnog imena, nego se s njim suočiti licem u lice. Upravo zbog toga nasilnik nije svestan štete koju nanosi drugoj osobi (Mandarić, 2012).

Izloženost jednom medijskom nasilju, ne pokazuje mnogo dokaza u prilog dugoročnijeg uticaja, pri čemu su efekti medijskog nasilja manje vidljivi. Dugoročni efekti izlaganju medijskog nasilja, uključuju procese učenja. Od detinjstva ljudi uče kako da doživljavaju, procenjuju, sude, i odgovore na događaje u fizičkom i drušvenom okruženju. Različite strukture saznanja se razvijaju tokom vremena. Oni su zasnovani na svakodnevnom posmatranju i interakciji sa drugim ljudima, realnim (kao npr. u porodici) i zamišljenim (kao u medijima). Svaki nasilan medij, je na neki način vrsta znanja o proceni, suđenju o situacijama u realnom životu (Anderson \& Bushman, 2001).

\section{PREDMET ISTRAŽIVANJA}

Pitanje koje se postavlja je pitanje kauzalnosti medija i agresivnosti. Da li izloženost medijskom nasilju zaista izaziva agresiju? Mnoga istraživanja, posebno tangentana i korelaciona, nisu mogla da determinišu smer uzročnosti. Zato je važno da se uzme u obzir i suprotna teorija: možda je kao inicijalna kapisla uvećanom nivou agresivnosti upravo u agresivnim sadržajima medija? Stavovi da izloženost medijskom nasilju izaziva agresivno ponašanje, izražava agresivnist ljudi koji imaju visok nivo kontrole ka nasilnom sadržaju. Vrlo je verovatno da dvosmerni efekti postoje, što znači da se kreću i u dvosmernim pravcima.

Stoga, predmet našeg istraživanja je prepoznavanje različitih posledica dečije izloženosti medijskom nasilju i subjekata koji su obuhvaćeni, kao i faktora koji povećavaju nivo agresivnosti usled medijskog uticaja nasilnih sadržaja.

\section{PROBLEM ISTRAŽIVANJA}

Nas je posebno zanimala kauzalna veza između medija i agresivnog ponašanja učenika. Dakle, problem ovog istraživanja je odgovor na pitanje da li mediji i agresivnost imaju uzročnoposledičnu efikasnost?

\section{CILJ I KARAKTER (STRATEGIJA) ISTRAŽIVANJA}

$\mathrm{Na}$ osnovu definisanja problema i predmeta istraživanja, osnovni cilj ovog teorijsko-kvalitativnog istraživanja jeste utvrđivanje posledica dečije izloženosti medijskom nasilju i faktora koji povećavaju nivo agresivnosti.

\section{TEORIJSKA INTERPRETACIJA}

Različite posledice dečije izloženosti medijskom nasilju ističu dva stanovišta, koja su povezana sa samim ponašanjem. Prvo, stavovi i percepcije realnosti kao posledica izloženosti medijskom nasilju i drugo, stepen tolerancije dece na nasilje i na agresiju u realnom životu (Molitor \& Hirsch, 1994). Ova dva efekta se na prvi pogled razlikuju od efekta agresivnog ponašanja, ali ipak utiču na širi aspekt interakcije. Ako stavovi dece podrazumevaju prihvatanje nasilja kao načina rešavanja problema, realno je očekivati da date u životnim situacijama reaguje nasiljem.

Deo faktora koji utiču na ponašanje je percepcija deteta o svetu koji ga okružuje. Problematika "neosećajnosti" je u vezi sa ponašanjem dece koja, odbijajući pomoć u realnom životu, kada se susretnu sa agresijom, u stvari ohrabruju nasilje. Razumno 
je da se misli da neosećajnost potiče od promena u ponašanju, koje je usmereno ka prihvatanju realnog nasilja u životu. Teško je reći kakav efekat je direktno prouzrokovan konzumacijom medijskog nasilja, ako je uopšte prouzrokovan. Stoga je važno uzeti u obzir i treću promenljivu koja se pojavljuje u efektima medijskog nasilja. Uzimajući u obzir pomenute promenljive, Heath (1989), su istakli da druge dve, principijalno različite promenljive, povećavaju agresivno ponašanje, nekada čak i bez povećane izloženosti medijskom nasilju.

Te dve promenljive su nedostatak jasnih normi protiv agresije u domu deteta i kod roditelja koji koriste psihičko kažnjavanje. Ove promenljive su i dobri indikatori veće ispitanosti medijskog nasilja u izvedenim eksperimentima, u poređenju sa decom u čijim domovima postoje jasne norme i/ili nikakvo psihičko kažnjavanje (Heath, 1989).

Faktori koji utiču na verovatnost da dete bude pogođeno agresivnim ponašanjem nakon konzumiranja nasilnog sadržaja su: Percepcija deteta ka nasilju kao realnoj pojavi, identifikacija deteta sa TV likovima i njegovo uverenje o društvenoj prihvatljivosti nasilja u globalu. Deca ne reaguju tako intenzivno kada su svesna fiktivnog elementa u medijskom sadržaju. Ona obično shvataju da pojedini sadržaji ne odgovaraju realnosti. Postoji i suprotna povezanost: Agresivnija deca veruju da je televizija realnija i stoga imitiraju ovakvo ponašanje.

Ako percepcija igra tako važnu ulogu u osnovnim efektima medijskog nasilja, kao treći faktor, može se pretpostaviti da promena percepcije takođe redukuje ovakav efekat. Retko koja studija je uzela u obzir ublažavanje efekata imitacije agresivnog ponašanja, ali studija Huesmana i ostalih (1983) je jedna od njih. Po mišljenju istraživača, uspeh studije podržava tezu da je verovanje dece u nasilje kao u prihvatljivo ponašanje u društvu, faktor agresivnog ponašanja. Studija je uspela u redukovanju efekta nasilnog medijskog sadržaja na agresiju na taj način što je spoznala kako deca aktivno reflektuju ponašanje na viđeno nasilno ponašanje. Istraživači su prepoznali da uzrast deteta, tokom dve godine, koliko je studija trajala, veoma kritičan period, jer nivo dečije agresije obično raste tokom godina, što je i bio slučaj sa kontrolnom grupom. Istraživači su pronašli da se percepcija medijskog nasilja od strane dece menja, i da se njihov nivo agresivnog ponašanja povećava mnogo manje nego kod dece iz kontrolne grupe. Štaviše, ovo se događa kada deca svoje navike koje se tiču medija značajno ne menjaju. Zaključak je bio da se nivo agresivnosti mora zaustaviti na određenom nivou u odnosu na konzumaciju medijskog sadržaja; u suprotnom, intervencija neće dati željene rezultate. Još jedan zaključak se nameće, a to je da je stav dece ka medijskom nasilju mnogo važniji od same izloženosti njemu. Medijsko nasilje je možda samo posredna promenljiva koja ukazuje da dete u inicijalnoj fazi pokazuje znake agresivnog ponašanja ili verovatnije, dete svojevoljno prihvata nasilje i tako dela agresivnije.

Poslednji faktor koji treba uzeti u obzir, u odnosu na pitanje uticaja medijskog nasilja, jeste način na koji medijsko nasilje izgleda u očima deteta, u poređenju sa objektivnim stavovima odraslih. Deca nisu samo ekrani koji imitiraju ono što je nekonvencionalno u njihovom okruženju.

Brojne eksperimentalne studije i istraživanja (Freedman, 1994; Cohen, et al, 1996; Anderson \& Bushman, 2001; Wilson, 2008) podržavaju hipotezu medijskog nasilja koje vodi u povećan nivo agresivnog ponašanja kod dece. Smatra se da je to naširoko podržana teza i nakon redefinisanja brojnih studija, evidentno je da je veza prisutna. Međutim, važno je da se ne izgubi u toj hipotezi i da posredne promenljive treba uzeti kao moguć razlog dečijeg nivoa agresije. Ova tematika preispituje da li su efekti podobni da budu izučavani u socijalnom vakumu. Lako je okriviti agresivnost kao posledicu medija, i kao ono što izaziva počinjena krivična dela u društvu ali je sigurno da su na to uticali brojni faktori kao što je inicijalni nivo agresivnosti koji je kod ljudi izražen, kao i okolina u kojoj čovek živi.

Posmatranje nasilja u medijima utiče ne samo na to deca uče agresivne postupke i nego čini da se svet vidi kao opasno mesto, što je pokazano i u našem teorijsko-kvalitativnom istraživanju. Takođe, posmatranje nasilja povećava verovatnoću da se nasilje vidi kao korisno sredstvo u rešavanju problema, može da proizvode ravnodušnost prema njemu i ujedno smanji saosećanje prema žrtvama nasilja. Iako su izloženi velikom broju nasilnih sadržaja, deca su i dalje osetljiva na nasilje i patnju drugih. Samo $6,3 \%$ dece izjavljuje da su ravnodušni nad nasiljem koje neka osoba preživljava. Ovakav podatak ukazuje da je negativni uticaj medija ipak ograničen, bar kod većine dece. Iako je nasilje u medijima veoma izraženo i očigledno ima efekte na decu pa ona tako vide svet kao nesigurno i opasno mesto, ohrabrujuća je informacija da učenici nisu postali ravnodušni na nasilje već ga i dalje prepoznaju kao nešto negativno.

S obzirom na to da nasilje u medijima ima ogrnaičen uticaj na mlade, postavlja se pitanje: Koji su to zaštitni faktori koji umanjuju i/ili neutrališu negativne efekte nasilja u medijima? Buduća istraživanja bi trebala da se pozabave identifikovanim problemom.

Mnoga deca i mladi, zbog zaposlenosti roditelja, nedostatka njihove pažnje, traže sagovornike preko društvenih mreža (Mandarić, 2012). Ovakvi podaci jasno potvrđuju da učenici provode sve više vremena na internetu i/ili gledajući televiziju i da mediji postaju ključni za socijalizaciju mladih kao i jedan od glavnih činioca koji utiče na promovisanje određenih društvenih vrednosti. Potencijalni problem je činjenica da roditelji nisu dovoljno uključeni niti informisani o sadržajima kojima su njihova deca izložena. Dodatni problem je to što dete koje provodi previše vremena na internetu ili gledajući televiziju smanjuje broj socijalnih interakcija sa vršnjacima i odraslima što vodi ka tome da dete ne razvija neophodne socijalne veštine. Posledično, nedostatak socijalnih veština može biti uzrok agresivnog ponašanja deteta koje ne razume da je njegovo ponašanje neodgovarajuće.

\section{REZIME}

Kada se nivoi stvarnosti više ne mogu razlikovati, odnosno, kada više ne mogu posredovati različiti kriterijumi koji omogućuju razlikovanje, kada svako odgovorno delovanje ne gubi samo svoj okvir orijentacije: onda više nije moguće ni razlikovanje između stvarnosti kakva ona zapravo jeste i kakva bi trebala biti. Celokupno delovanje na moralne vrednosti mladih postaje nemoguće, postaje svejedno, degradirano do igre. U skladu sa tim, i takozvana stvarnost postaje puka iluzija. Etički relevantni prostor delovanja postaje igralište samovoljne manipulacije. Etičko delovanje gubi u maglovite rekonstrukcije i dekonstrukcije. Ono se zapravo zamenjuje neodgovornim konstruktima stvarnosti (Burić, 2010).

Podsticanje komunikacijskih veština dece kao i promovisanje asertivnog, a ne agresivnog ponašanja moglo bi da dovede do smanjivanja pojave agresivnog ponašanja dece i mladih.

Kao poseban problem ističe se pitanje: Da li dete koje je previše izloženo medijskim uticajima može da razvije neophodne socijalne veštine koje će mu pomoći u građenju adekvatnih socijalnih odnosa sa drugima? Nedostatak socijalnih veština može biti uzrok agresivnog ponašanja deteta, ali i faktor koji će povećati šansu da neko dete postane žrtva nasilničkog ponašanja drugih. Dakle, roditelji moraju da ograniče vreme koje dete provodi na internetu/ispred televizora kao i da kontrolišu sadržaje kojima je dete izloženo. Osim toga, neophodno je da 
podstiču socijalne veštine deteta kao i da steknu i neguju odnos pun poverenja i podrške. Na taj način moguće je smanjiti negativni uticaj medija.

S obzirom da percepcija ličnosti igra važnu ulogu u osnovnim efektima medijskog nasilja, može se pretpostaviti da promena percepcije može redukovati ovakav efekat. Jedna od mogućih strategija koja otklanja negativne efekte medija jeste sticanje medijske kompetentnosti koja omogućava pojedincu da se zaštiti od manipulacije medija, ali da istovremeno iskoristi pozitivne aspekte istih. Kako bi uspeh strategije bio delotvoran, potrebno je upoznati se sa navikama mladih, učestalošću korišćenja medija, sadržajem medija kao i proveriti aktuelni nivo medijske kompetencije. Ipak, čini se da nisu svi aspekti medijske kompetencije na istom odgovarajućem nivou pa je svakako neophodna dalja edukacija kako bi se negativni uticaj medija na agresivno ponašanje dece i mladih sprečio i/ili sveo na minimum. Edukacija odraslih o ovim problemima pomogla bi indirektno i deci koja bi na taj način mogla da koriste više izvora za učenje.

\section{LITERATURA}

Anderson, C.A., \& Bushman, J.B. (2001). Effects of violent video games on aggressive behavior, aggressive cognition, aggressive affect, physiological arousal, and prosocial behavior: A meta-analytic review of the scientific literature. Psychological science, 12(5), 353-359.

Bilić, V. (1999). Agresivnost mladih i mogućnost pomoći. Obnovljeni život, 54(1), 69-77.
Burić, J. (2010). Djeca i mladi kao konzumenti masovnih medija. Filozofska istraživanja, 4(2), 629-663.

Cohen, D., Nisbett, R., Bowdle, B., \& Schwarz, N. (1996). Insult, Aggression, and the Southern Culture of Honor: An "Experimental Ethnography". Journal of Personality and Social Psychology, 70(5), 945-960.

Dmitrović, M. (2011). Uticaj televizije, crtanih filmova i kompjuterskih igrica na porast nasilja kod dece. Socijalna misao, 18(3), 45-64.

Freedman, J. (1994). Viewing television violence does not make people more aggressive. Hofstra Law Review, 22, 833-854.

Huesman L.R, Eron L.D., Klein R., Brice, P., \& Fischer, P. (1983). Mitigating the imitation of agressive behaviors by changing children's attitudes about media violence. Journal of Personality and Social Psychology, 44, 899-910.

Mandarić, V. (2012). Novi mediji i rizično ponašanje djece i mladih. Bogoslovska smotra, 82(1), 131-149.

Molitor, F., \& Hirsch, K.W. (1994). Childrens Toleration of Real-life aggression after exposure to media violence. Journal Child Study, 24, 191-207.

Popadić, D. (2009). Nasilje u školama. Beograd: Institut za psihologiju.

Stanić, I. (2008). Agresija kod mladih i njeno suzbijanje. Pedagoška stvarnost, 54(1-2), 147-163.

Stojković, N. (2012). Televizija i njene vaspitno-obrazovne mogućnosti. Pedagoška stvarnost, 58(2), 280-294.

Wilson, B. (2008). Media and children's aggression, fear and altruism. The Future of children, 18(1) 87-118. 